\title{
Wind Energy Potential Assessment of Coastal States in South-South Nigeria Based on the Weibull Distribution Model
}

\author{
Hachimenum Nyebuchi Amadi
}

\begin{abstract}
Energy has since become the global index for assessment of standard of living for socio-economic and industrial development. Worldwide, energy demand is rising with increasing population. Conventional energy sources such as fossil fuels are unsustainable and environmentally-unfriendly. Alternative sources of energy such as the sun, the wind etc. that are sustainable and less harmful to the environment need be exploited to meet the ever rising demand for energy, to avoid energy deficit. This paper investigated the wind energy potential of three locations in south-south Nigeria. Wind speed data measured at 10-metres height over the period 2013-2017 obtained from the Nigerian Meteorological Agency (NiMet) for Yenagoa, Calabar and Port Harcourt were evaluated using the Weibull two-parameter probability distribution model to ascertain the wind energy potential of the respective locations. The study outcome shows that during the study period, the monthly mean wind speed varied between $1.2 \mathrm{~m} / \mathrm{s}$ in November and $2.3 \mathrm{~m} / \mathrm{s}$ in February for Yenagoa. The same varied between $2.2 \mathrm{~m} / \mathrm{s}$ in July and $3.7 \mathrm{~m} / \mathrm{s}$ in February for Calabar but ranged between $1.0 \mathrm{~m} / \mathrm{s}$ in July to $1.6 \mathrm{~m} / \mathrm{s}$ in February for Port Harcourt. The annual mean wind speeds for Yenagoa, Calabar and Port Harcourt were $1.74 \mathrm{~m} / \mathrm{s}, 2.85 \mathrm{~m} / \mathrm{s}$ and $1.38 \mathrm{~m} / \mathrm{s}$ respectively. The annual mean power densities for Yenagoa, Calabar and Port Harcourt were found to be $4.64 \mathrm{~W} / \mathrm{m}^{2}, 7.06 \mathrm{~W} / \mathrm{m}^{2}$ and $3.08 \mathrm{~W} / \mathrm{m}^{2}$ respectively while the corresponding values of the annual mean energy densities were $3.24 \mathrm{KW} / \mathrm{m}^{2}, 4.93 \mathrm{KW} / \mathrm{m}^{2}$ and $2.14 \mathrm{KW} / \mathrm{m}^{2}$ respectively. The study reveal that though wind energy in the study areas is sufficient only for standalone power generating systems, water pumping and applications requiring less power, higher value of wind energy is possible if wind speed data were collected at heights above the $10 \mathrm{~m}$ implemented in the study.
\end{abstract}

Index Terms - Energy Shortage, Renewable Energy, Wind Energy, Wind Speed, Weibull Parameters

\section{INTRODUCTION}

Globally, energy is the index for assessment of the standard of living necessary for socio-economic and industrial development. Energy plays a central role in economic development and industrialization of any nation as it stimulates productive activities in all sectors of a nation's economy including industry, commerce, agriculture and

Published on December 25, 2018.

H. N. Amadi is with the Department of Electrical and Electronic Engineering of the Federal University of Technology, Owerri, Nigeria (amadihachy@gmail.com). mining [1]. Per capita energy consumption is therefore a measure of the per capita income as well as a measure of the prosperity of a nation [2].

The world's population has been estimated to reach 8 billion by 2020 [3] and given the fact that global energy demand is growing exponentially coupled with the claim by recent researchers that conventional energy resources are limited on earth, governments and policymakers must devise new energy sources that are not only renewable but also less harmful to the environment. Energy shortage is a global issue and a major challenge particularly among the developing countries including Nigeria where about 1.6 billion people are without to electricity [4][5][6][7]. Nigeria's electrical energy demand being high, the country is faced with perennial acute energy shortage despite being blessed with vast natural resources [8]. The country's energy is supplied from hydropower which water level varies according to seasonal changes and from thermal power stations which are affected by lack of adequate supplies of natural gas from the country's gas wells [9]. With a projected rate of fossil fuel depletion in 40 years and her desire to become an industrialized economy, Nigeria needs alternative sources of affordable, clean and sustainable energy to meet its growing energy demand to evade stumbling into an energy supply crisis [10][2].

Many indigenous researchers have investigated wind energy availability in Nigeria and the potential for power generation and utilization and have concluded that wind energy is an alternate source of energy that can be exploited to meet the needs of the nation [11]. It has been found also that wind speed in Nigeria ranges from $1.4-3.0 \mathrm{~m} / \mathrm{s}$ in the southern areas and $4.0-5.12 \mathrm{~m} / \mathrm{s}$ in the extreme north. Recent studies show, however, that wind speeds are weak in the southern part of the country except for the coastal and the offshore regions [12]. Reference [13] evaluated wind speed data of 30 stations in Nigeria and discovered that the annual mean wind speeds and power flux densities vary from 1.5 $4.1 \mathrm{~m} / \mathrm{s}$ to $5.7-22.5 \mathrm{~W} / \mathrm{m}^{2}$, respectively. Similarly, Reference [14] investigated wind speed data from 1951-1975 from 22 stations across the country and discovered that Sokoto area (in the northern part) recorded highest wind speed of about $5.12 \mathrm{~m} / \mathrm{s}$ in June and annual average of $3.92 \mathrm{~m} / \mathrm{s}$. These researchers also reported wind speed of about $2 \mathrm{~m} / \mathrm{s}$ in the middle-belt and the southern areas of Nigeria.

According to Reference [15], wind energy reserve in Nigeria at $10 \mathrm{~m}$ height reveals that some sites have wind regime between 1.0 and $5.1 \mathrm{~m} / \mathrm{s}$, and show that Nigeria falls into the poor/moderate wind regime. It has been reported also 
that wind speeds in the country are generally weak in the south except for the coastal regions and offshore, which are windy. Offshore areas from Lagos through Ondo, Delta, Rivers, Bayelsa to Akwa Ibom States were reported to have potentialities for harvesting strong wind energy throughout the year. The values for the wind speeds range from 1.4 to 3.0 $\mathrm{m} / \mathrm{s}$ in the southern areas and 4.0 to $5.12 \mathrm{~m} / \mathrm{s}$ in the extreme North, at $10 \mathrm{~m}$ height. Other independent studies on the wind speed pattern across Nigeria, for example, Reference [13] based on wind data from 30 Meteorological Stations and Reference [16] based on wind data for 18 stations and from 1979-1988, all confirmed the findings by the aforementioned researches. Reference [16] specifically stated that the average wind speeds in Nigeria are within the range of about $2 \mathrm{~m} / \mathrm{s}$ to about $4 \mathrm{~m} / \mathrm{s}$ with highest average speeds of about $3.5 \mathrm{~m} / \mathrm{s}$ and $7.5 \mathrm{~m} / \mathrm{s}$ in the southern and the northern areas, respectively [17]. Generally, wind speed is known to be usually large at high altitudes and coastal areas [18][19].

More countries are adopting wind energy technology as a viable means for power generation. In the year 2010, global wind capacity reached 196,630 MW. This is after reaching $159,050 \mathrm{MW}$ in 2009, 120,903 MW in 2008, and 93,930 MW in 2007. In 2010, $9918 \mathrm{MW}$ of wind power was installed across Europe. Of this amount, the European Union countries alone accounted for a whopping 9295 MW [18][20][21]. Nigeria must join this league of countries to achieve energy security. Accurate wind resource assessment is a prerequisite in the choice of a location for efficient wind turbine sitting and wind power harnessing under economic, social and environmental constraints [22]. The work investigated the wind energy potential of the coastal region of south-south Nigeria and therefore the viability of wind as an alternative and sustainable energy source to conventional energy sources.

\section{MATERIALS AND METHODS}

The five year (2013-2017) monthly mean wind speed data used for this study were obtained from the Nigeria Meteorological Agency (NiMet), Oshodi-Lagos, Nigeria. The data were measured continuously using the cup generator anemometer at a height of $10 \mathrm{~m}$ above sea level. Table 1 presents information about the study locations. The data were evaluated using the two-parameter Weibull probability distribution function in order to determine the monthly mean and annual mean wind resource potentials for power generation in the studied coastal areas of Nigeria.

TABLE 1. GEOGRAPHICAL LOCATION OF THE STATES OF SOUTH-SOUTH, NIGERIA

\begin{tabular}{|c|c|c|c|c|}
\hline State & Capital & Longitude $\left({ }^{\circ} \mathrm{N}\right)$ & Latitude $\left({ }^{0} \mathrm{~W}\right)$ & Elevation (M) \\
\hline $\begin{array}{l}\text { Akwa } \\
\text { Ibom }\end{array}$ & Uyo & 7.93 & 5.05 & 68.0 \\
\hline Bayelsa* & Yenagoa & $6.26 \leq$ & 4.92 & 206 \\
\hline Cross River* & Calabar & 8.32 & 4.95 & 13.0 \\
\hline Delta & Asaba & 6.18 & 6.75 & 43.0 \\
\hline Edo & Benin & 5.6 & 6.32 & 375.0 \\
\hline Rivers* & $\begin{array}{l}\text { Port- } \\
\text { Harcourt }\end{array}$ & 7.00 & 4.75 & 19.5 \\
\hline
\end{tabular}

* States covered by the Study
Before deciding whether or not to locate a wind turbine in an area, it is normal to first ascertain the wind characteristics of the area. This study adopted the Pacific North-West Laboratory (PNL) Wind Power Classification Scheme shown in Table 2. As can be seen in the Table, wind power has been classified for three different heights of $10 \mathrm{~m}, 30 \mathrm{~m}$ and $50 \mathrm{~m}$ and into seven different classes ranging from the lowest Class 1 to the highest Class 7 .

TABLE 2: PACIFIC NORTH-WEST LABORATORY (PNL) WIND POWER CLASSIFICATION SCHEME [23][24]

\begin{tabular}{lllllll}
\hline \hline $\begin{array}{l}\text { Wind } \\
\text { Power }\end{array}$ & $\begin{array}{l}10 \mathrm{~m} \\
\text { Wind }\end{array}$ & $\begin{array}{l}10 \mathrm{~m} \\
\text { Wind }\end{array}$ & $\begin{array}{l}30 \mathrm{~m} \\
\text { Wind }\end{array}$ & $\begin{array}{l}30 \mathrm{~m} \\
\text { Wind }\end{array}$ & $\begin{array}{l}50 \mathrm{~m} \\
\text { Wind }\end{array}$ & $\begin{array}{l}50 \mathrm{~m} \\
\text { Wind }\end{array}$ \\
& $\begin{array}{l}\text { Power } \\
\left(\mathrm{W} / \mathrm{m}^{2}\right)\end{array}$ & $\begin{array}{l}\text { Speed } \\
(\mathrm{m} / \mathrm{s})\end{array}$ & $\begin{array}{l}\text { Power } \\
\left(\mathrm{W} / \mathrm{m}^{2}\right)\end{array}$ & $\begin{array}{l}\text { Speed } \\
(\mathrm{m} / \mathrm{s})\end{array}$ & $\begin{array}{l}\text { Power } \\
\left(\mathrm{W} / \mathrm{m}^{2}\right)\end{array}$ & $\begin{array}{l}\text { Speed } \\
(\mathrm{m} / \mathrm{s})\end{array}$ \\
\hline 1 & $\leq 100$ & $\leq 4.4$ & $\leq 160$ & $\leq 5.1$ & $\leq 200$ & $\leq 5.6$ \\
2 & $\leq 150$ & $\leq 5.1$ & $\leq 240$ & $\leq 6.0$ & $\leq 330$ & $\leq 6.4$ \\
3 & $\leq 200$ & $\leq 5.6$ & $\leq 320$ & $\leq 6.5$ & $\leq 400$ & $\leq 7.0$ \\
4 & $\leq 250$ & $\leq 6.0$ & $\leq 400$ & $\leq 7.0$ & $\leq 500$ & $\leq 7.5$ \\
5 & $\leq 300$ & $\leq 6.4$ & $\leq 480$ & $\leq 7.5$ & $\leq 600$ & $\leq 8.0$ \\
6 & $\leq 400$ & $\leq 7.0$ & $\leq 640$ & $\leq 8.2$ & $\leq 800$ & $\leq 8.8$ \\
7 & $\leq 1000$ & $\leq 9.4$ & $\leq 1600$ & $\leq 11.0 \leq 2000$ & $\leq 11.9$ \\
\hline \hline
\end{tabular}

\section{A. Data Analyses}

It was considered necessary to measure the wind data at a height of $10 \mathrm{~m}$ as that is the standard meteorological reference level (from both climatological and practical reasons) to achieve representative recordings of the wind potential of study locations [25]. The study used the Weibull twoparameter statistical distribution function. Recent studies confirmed that the Weibull two-parameter distribution function is a standard approach for evaluating wide collection of wind data and for predicting the characteristics of prevailing local wind profiles [26][27][28][29][30]. The technique has also been known to give a better and superior fit for wind speed data when compared to either the Rayleigh distribution or the Lognormal distribution [29][30][31][32].

The two-parameter Weibull Probability Density Function (PDF) with scale (c) and shape (k) being the parameters. The Probability Density Function (PDF) and the corresponding Cumulative Density Function (F (v)) associated with the twoparameter Weibull distribution are given by Equations (1) and (2) respectively [33][34]:

$$
f(v)=(k / c)(v / c)^{k-1} \exp \left[-(v / c)^{k}\right]
$$

The corresponding cumulative probability function of the Weibull distribution is given by the equation:

$$
F(v)=1-\exp \left[-(v / c)^{k}\right]
$$

The wind power density function $\left(\mathrm{W} / \mathrm{m}^{2}\right)$ as the quantitative measure of the wind energy available at any given location can be estimated from the Weibull Parameters as: 
$p(v)=1 / 2 \rho_{c}^{3}(1+3 / k)$

Where $p(v)=$ wind power density, $\rho=$ air density.

The determination of $\mathrm{k}$ and c called parameters of Weibull makes it possible to ascertain the wind speed distribution for any given site. The two parameters $k$ and $c$ of Weibull Probability Density Function, are related to the mean wind speed $v_{m}$ and standard deviation $\sigma$ by the equation:

$k=\left(\sigma / v_{m}\right)^{-1.086}$

$c=v_{m} / \Gamma(1+1 / k)$

The mean value of the wind speed, $v_{m}$, and standard deviation, $\sigma$, for the Weibull distribution is defined in terms of the Weibull parameters, $k$ and $c$, as [30][35]:

$v_{m}=c \Gamma(1+1 / k)$

$\sigma=c\left[\Gamma(1+2 / k)-\Gamma^{2}(1+1 / k)\right]^{1 / 2}$

Where $\Gamma$ is the gamma function (Standard Formula).

Tables 3, 4 and 5 show the monthly and mean wind speed for 2013-2017 in Yenagoa in Bayelsa State, Calabar in Cross River State and Port Harcourt in Rivers State respectively.

TABLE 3: MONTHLY AND MEAN WIND SPEED FOR 2013-2017 IN YENAGOA, BAYELSA STATE

\begin{tabular}{lcccccc}
\hline $\begin{array}{l}\text { Month/ } \\
\text { Year }\end{array}$ & 2013 & 2014 & 2015 & 2016 & 2017 & $\begin{array}{c}\text { Mean Wind Speed } \\
(\mathrm{m} / \mathrm{s})\end{array}$ \\
\hline January & 1.608 & 3.138 & 1.215 & 2.375 & 1.271 & 1.9 \\
February & 3.156 & 3.306 & 3.392 & 0.786 & 1.044 & 2.3 \\
March & 1.344 & 3.113 & 1.665 & 0.993 & 1.641 & 1.8 \\
April & 2.324 & 3.361 & 2.248 & 1.010 & 1.014 & 2.0 \\
May & 3.321 & 1.818 & 1.727 & 0.770 & 0.579 & 1.6 \\
June & 1.723 & 2.332 & 1.018 & 1.145 & 1.277 & 1.5 \\
July & 1.325 & 1.783 & 0.614 & 1.062 & 1.233 & 1.2 \\
August & 1.480 & 2.011 & 0.623 & 1.085 & 1.416 & 1.3 \\
September & 0.701 & 2.345 & 1.415 & 1.286 & 1.422 & 1.4 \\
October & 1.400 & 2.666 & 1.289 & 1.371 & 1.688 & 1.7 \\
November & 1.823 & 2.340 & 1.314 & 1.376 & 2.168 & 1.8 \\
December & 1.942 & 2.566 & 1.456 & 1.571 & 2.675 & 2.0 \\
\hline \hline
\end{tabular}


11.5 in September for Calabar whereas for Port Harcourt, it ranged from 1.6 in May to 5.0 in September.

Figure 2 represents the monthly probability distribution function (at $10 \mathrm{~m}$ height) over Yenagoa, Calabar and Port Harcourt during the study period (2013-2017). The monthly probability distribution function values were found to range from 0.5 in February to 1.8 in September for Yenagoa. The values ranged from 0.7 in February to 2.8 in September for Calabar whereas it varied from 0.3 in February to 1.2 in September for Port Harcourt. Figure 3 shows the probability distribution function versus wind speed (at 10m height) over Yenagoa, Calabar and Port Harcourt in South-South Nigeria for the period 2013-2017.

The relationship between cumulative distribution function and wind speed (at $10 \mathrm{~m}$ height) over Yenagoa, Calabar and Port Harcourt as obtained during the study period is represented in Figure 4 while Figure 5 shows the relationship between the annual mean wind power density and the mean wind speed (at 10m height) over Yenagoa, Calabar and Port Harcourt. Figure 6 represented the relationship between wind energy density and wind speed (at $10 \mathrm{~m}$ height) over Yenagoa, Calabar and Port Harcourt.

These results demonstrate that the wind profiles for the study locations followed the same cumulative distribution pattern throughout the study period.

TABLE 6: COMPUTED MONTHLY MEAN WIND SPEED, ANNUAL MEAN ENERGY DENSITY, ANNUAL MEAN POWER DENSITY ETC. FOR 2013-2017 AT HEIGHT 10M IN YENAGOA, BAYELSA STATE

\begin{tabular}{lcccccc}
$\begin{array}{l}\text { Month/ } \\
\text { Year }\end{array}$ & 2013 & 2014 & 2015 & 2016 & 2017 & $\begin{array}{c}\text { Mean Wind Speed } \\
(\mathrm{m} / \mathrm{s})\end{array}$ \\
\hline January & 1.608 & 3.138 & 1.215 & 2.375 & 1.271 & 1.9 \\
February & 3.156 & 3.306 & 3.392 & 0.786 & 1.044 & 2.3 \\
March & 1.344 & 3.113 & 1.665 & 0.993 & 1.641 & 1.8 \\
April & 2.324 & 3.361 & 2.248 & 1.010 & 1.014 & 2.0 \\
May & 3.321 & 1.818 & 1.727 & 0.770 & 0.579 & 1.6 \\
June & 1.723 & 2.332 & 1.018 & 1.145 & 1.277 & 1.5 \\
July & 1.325 & 1.783 & 0.614 & 1.062 & 1.233 & 1.2 \\
August & 1.480 & 2.011 & 0.623 & 1.085 & 1.416 & 1.3 \\
September & 0.701 & 2.345 & 1.415 & 1.286 & 1.422 & 1.4 \\
October & 1.400 & 2.666 & 1.289 & 1.371 & 1.688 & 1.7 \\
November & 1.823 & 2.340 & 1.314 & 1.376 & 2.168 & 1.8 \\
December & 1.942 & 2.566 & 1.456 & 1.571 & 2.675 & 2.0 \\
\hline \hline
\end{tabular}

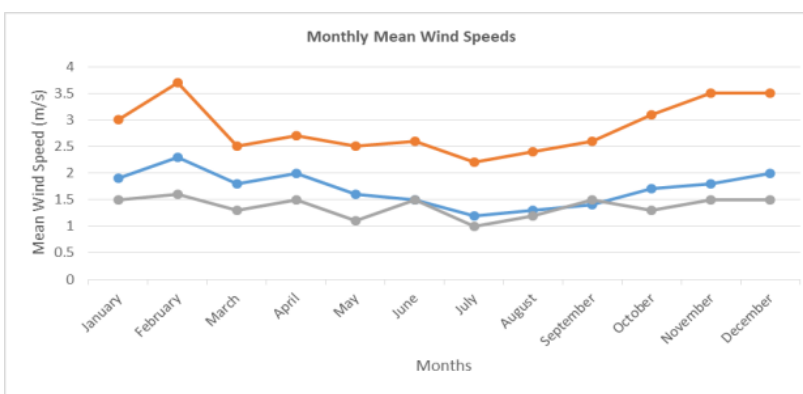

Figure 1. Monthly Mean Wind Speeds (at $10 \mathrm{~m}$ height) over Yenagoa, Calabar and Port Harcourt in South-South Nigeria for the Period 2013-2017.
TABLE 7: COMPUTED MONTHLY MEAN WIND SPEED, ANNUAL MEAN ENERGY DENSITY, ANNUAL MEAN POWER DENSITY ETC. FOR 2013-2017 AT HEIGHT 10M IN CALABAR, CROSS RIVER STATE

\begin{tabular}{lcccccccc}
\hline \hline Month & $v_{m}$ & $\sigma$ & $k$ & $c$ & $A P D$ & $A E D$ & $F(V)$ & $f(v)$ \\
\hline January & 3.0 & 0.9 & 6.4 & 3.5 & 5.5 & 3.9 & 0.9 & 1.2 \\
February & 3.7 & 1.4 & 4.6 & 4.1 & 18.6 & 13.1 & 1.2 & 0.7 \\
March & 2.5 & 1.6 & 5.3 & 3.2 & 6.2 & 4.6 & 1.4 & 1.4 \\
April & 2.7 & 1.4 & 6.2 & 4.4 & 11.7 & 8.1 & 0.9 & 1.2 \\
May & 2.5 & 1.2 & 3.7 & 2.8 & 5.8 & 4.6 & 1.6 & 1.4 \\
June & 2.6 & 0.9 & 6.4 & 3.2 & 6.4 & 3.9 & 1.4 & 1.6 \\
July & 2.2 & 0.7 & 5.3 & 2.8 & 1.6 & 1.6 & 0.9 & 1.4 \\
August & 2.4 & 1.2 & 6.4 & 3.5 & 13.3 & 8.1 & 0.9 & 1.4 \\
September & 2.6 & 0.9 & 11.5 & 3.0 & 3.0 & 2.8 & 1.2 & 2.8 \\
October & 3.1 & 0.9 & 7.8 & 3.0 & 4.1 & 2.5 & 1.2 & 1.8 \\
November & 3.5 & 1.2 & 7.6 & 2.3 & 3.0 & 1.4 & 0.9 & 2.3 \\
December & 3.5 & 0.7 & 5.8 & 3.5 & 5.5 & 4.6 & 0.7 & 1.6 \\
\hline \hline
\end{tabular}

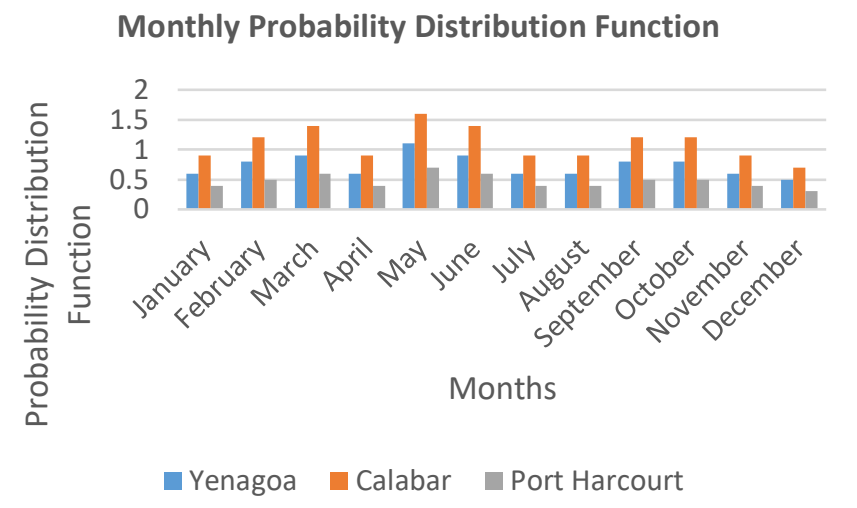

Figure 2. Monthly Probability Distribution Function (at 10m height) over Yenagoa, Calabar and Port Harcourt in South-South Nigeria for the Period 2013-2017.

TABLE 8: COMPUTED MONTHLY MEAN WIND SPEED, ANNUAL MEAN ENERGY DENSITY, ANNUAL MEAN POWER DENSITY ETC. FOR 2013-2017 AT HEIGHT 10M IN PORT HARCOURT, RIVERS STATE

\begin{tabular}{lcccccccc}
\hline \hline Month & $v_{m}$ & $\sigma$ & $k$ & $c$ & $A P D$ & $A E D$ & $F(V)$ & $f(v)$ \\
\hline January & 1.5 & 0.4 & 2.8 & 1.5 & 2.4 & 1.7 & 0.4 & 0.5 \\
February & 1.6 & 0.6 & 2.0 & 1.8 & 8.1 & 5.7 & 0.5 & 0.3 \\
March & 1.3 & 0.7 & 2.3 & 1.4 & 2.7 & 2.0 & 0.6 & 0.6 \\
April & 1.5 & 0.6 & 2.7 & 1.9 & 5.1 & 3.5 & 0.4 & 0.5 \\
May & 1.1 & 0.5 & 1.6 & 1.2 & 2.5 & 2.0 & 0.7 & 0.6 \\
June & 1.5 & 0.4 & 2.8 & 1.4 & 2.8 & 1.7 & 0.6 & 0.7 \\
July & 1.0 & 0.3 & 2.3 & 1.2 & 0.7 & 0.7 & 0.4 & 0.6 \\
August & 1.2 & 0.5 & 2.8 & 1.5 & 5.8 & 3.5 & 0.4 & 0.6 \\
September & 1.5 & 0.4 & 5.0 & 1.3 & 1.3 & 1.2 & 0.5 & 1.2 \\
October & 1.3 & 0.4 & 3.4 & 1.3 & 1.8 & 1.1 & 0.5 & 0.8 \\
November & 1.5 & 0.5 & 3.3 & 1.0 & 1.3 & 0.6 & 0.4 & 1.1 \\
December & 1.5 & 0.3 & 2.5 & 1.5 & 2.4 & 2.0 & 0.3 & 0.7 \\
\hline \hline
\end{tabular}

Where:

$\begin{array}{ll}\text { MW } & \text { Megawatt } \\ \mathrm{V}_{\mathrm{M}} & \text { Mean Wind Speed }(\mathrm{m} / \mathrm{s}) \\ \sigma & \text { Standard Deviation } \\ \mathrm{K} & \text { Dimensionless Weibull Shape Parameter } \\ \mathrm{C} & \text { Weibull Scale Parameter } \\ \text { APD } & \text { Average Power Density }\left(\mathrm{W} / \mathrm{m}^{2}\right) \\ \text { AED } & \text { Average Energy Density }\left(\mathrm{Kwh} / \mathrm{m}^{2}\right) \\ \mathrm{F}(\mathrm{V}) & \text { Cumulative Distribution Frequency } \\ \mathrm{f}(\mathrm{v}) & \text { Probability Distribution Function } \\ \Gamma & \text { Gamma function }\end{array}$




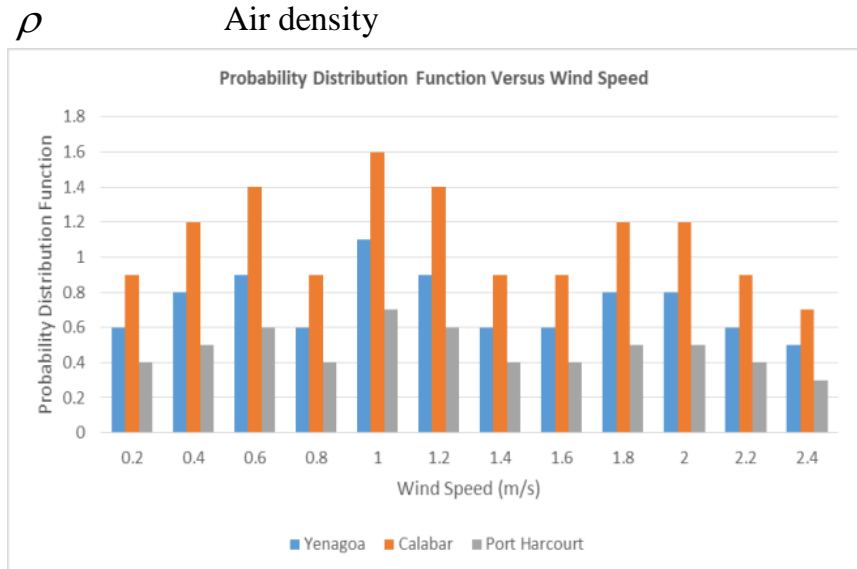

Figure 3. Probability Distribution Function Versus Wind Speed (at 10m height) over Yenagoa, Calabar and Port Harcourt in South-South Nigeria for the Period 2013-2017.

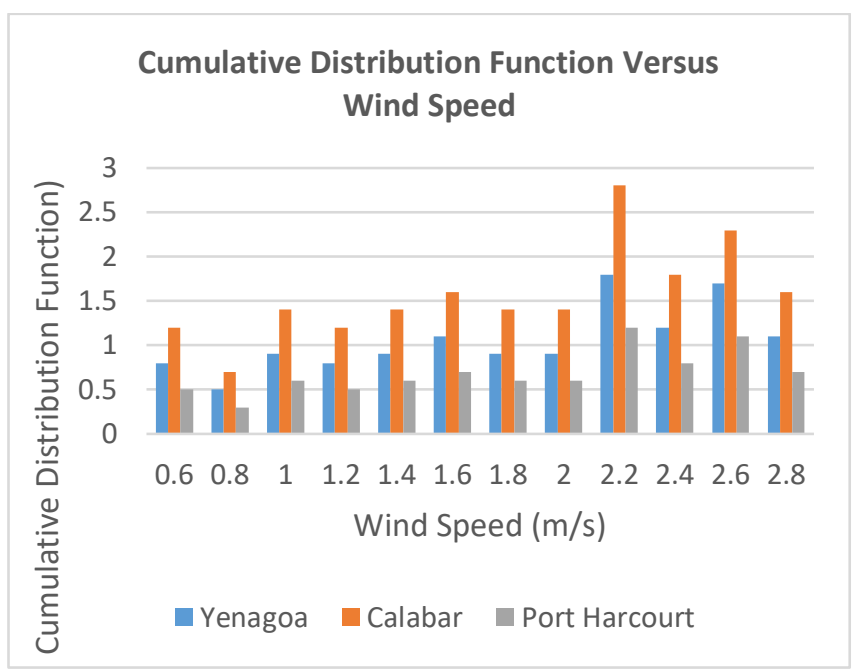

Figure 4. Cumulative Distribution Function Versus Wind Speed (at 10m height) over Yenagoa, Calabar and Port Harcourt in South-South Nigeria for the Period 2013-2017.

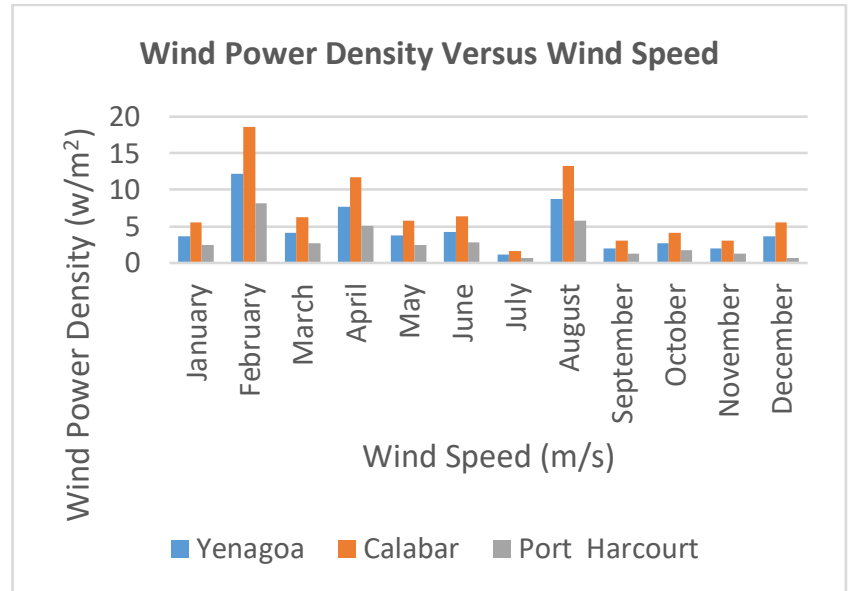

Figure 5. Wind Power Density Versus Wind Speed (at 10m height) over Yenagoa, Calabar and Port Harcourt in South-South Nigeria for the Period 2013-2017.

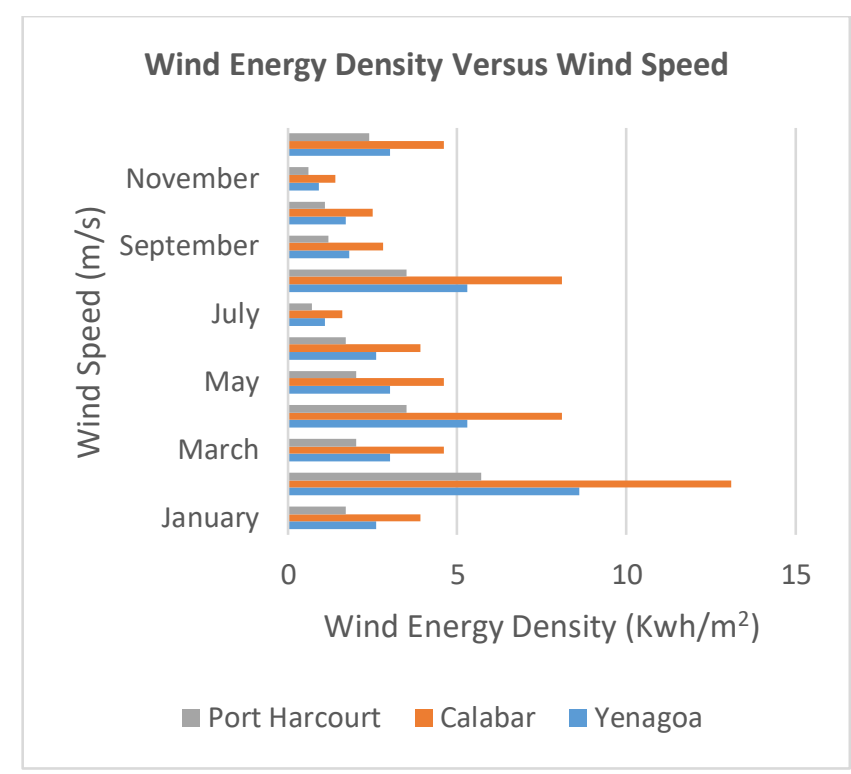

Figure 6. Wind Energy Density Versus Wind Speed (at 10m height) over Yenagoa, Calabar and Port Harcourt in South-South Nigeria for the Period 2013-2017.

\section{CONCLUSION}

In this study, the wind energy potential of three stations within the coastal region of South-South Nigeria was investigated by determining the monthly mean wind speed, annual mean energy density and annual mean power density for each of the stations during the period 2013-2017. The analyses were done on the basis of the Weibull distribution function parameters, using the monthly mean wind speed data at 10-metre height obtained from the Nigerian Meteorological Agency (NiMet), Oshodi-Lagos, Nigeria. From the findings of this study, the following conclusions can be drawn:

(1) The annual mean wind speeds for Yenagoa, Calabar and Port Harcourt are $1.74 \mathrm{~m} / \mathrm{s}, 2.85 \mathrm{~m} / \mathrm{s}$ and $1.38 \mathrm{~m} / \mathrm{s}$ respectively.

(2) The mean annual values of the Weibull shape parameter, $\mathrm{k}$ for Yenagoa, Calabar and Port Harcourt are 4.2, 6.42 and 2.79 respectively. The corresponding values of the Weibull scale parameter, $\mathrm{C}$ are 2.2, 3.28 and 1.42 respectively.

(3) The annual mean power densities for Yenagoa, Calabar and Port Harcourt are $4.64 \mathrm{~W} / \mathrm{m} 2,7.06 \mathrm{~W} / \mathrm{m} 2$ and $3.08 \mathrm{~W} / \mathrm{m} 2$ respectively.

(4) The values of the annual mean energy densities are 3.24 $\mathrm{KW} / \mathrm{m} 2,4.93 \mathrm{KW} / \mathrm{m} 2$ and $2.14 \mathrm{KW} / \mathrm{m} 2$ respectively.

Since the mean wind speed and mean power density to classify the energy resourcefulness of a study location, it can be concluded therefore that the energy resource in the investigated areas along the coastal south-south Nigerian region is low and classifiable into Class 1 [23][24]. It is possible, however, to achieve higher values of wind speed, annual power density and therefore higher wind energy resource if data were collected at heights above the $10 \mathrm{~m}$ used for the study since wind speed increases with the height at which study data are collected. The study findings stress the need to embrace wind energy as a healthy and viable 
alternative to energy sourced from conventional sources as currently in practice in Nigeria.

\section{REFERENCES}

[1] H. N. Amadi, E. N.C. Okafor and F. I. Izuegbunam (2016). “Assessment of Energy Losses and Cost Implications in the Nigerian Distribution Network." American Journal of Electrical and Electronic Engineering, vol. 4, no. 5 (2016): 123-130. doi: 10.12691/ajeee-4-5-1.

[2] Oyedepo, S.O. (2012). "Energy and sustainable development in Nigeria: the way forward", Energy, Sustainability and Society, 2:15. Available at http://www.energsustainsoc.com/content/2/1/15

[3] United Nations, Department of Economic and Social Affairs, Population Division (2017). World Population Prospects: The 2017 Revision. New York: United Nations.

[4] H. N. Amadi (2015a). "Impact of Power Outages on Developing Countries: Evidence from Rural Households in Niger Delta, Nigeria." Journal of Energy Technologies and Policy, Vol.5, No.3, 2015: 27-38

[5] Chineke, C.T. (2009). Boosting Electricity Supply in Nigeria: Wind Energy to the Rescue? The Pacific Journal of Science and Technology, Volume 10. Number 2. November 2009 (Fall)

[6] Chineke, T.C. and E.C. Igwiro. 2008. "Urban and Rural Electrification: Enhancing the Energy Sector in Nigeria using Photovoltaic Technology". African Journal of Science and Tech. 9(1):102-108

[7] International Energy Outlook. 2006. Available Online at: http://en.wikipedia.org/wiki/Energy Information Administration

[8] H.N. Amadi (2015b). "Power Outages in Port Harcourt City: Problems and Solutions", IOSR Journal of Electrical and Electronics Engineering, 10(2), Vers. III, pp.59-66

[9] Iwayemi, A., Nigeria's dual energy problems: Policy issues and challenges, International Association for energy economics, Fourth Quarter, 2008, available online at http//:www.iaee.org/en/publications/newsletterdl.aspx? id=53

[10] Shaaban, M. \& Petinrin, J.O. Renewable energy potentials in Nigeria: Meeting rural energy needs. Renewable and Sustainable Energy Reviews, 29 (2014) 72-84

[11] Uchendu, O.A. (1993). Economic costs of electricity outages: evidence from sample study of industrial and commercial firms in Lagos area of Nigeria. CBN Economic and Financial Review. 31:183195

[12] Idris N.A., Lamin, H.S., Ladan, M.J. and Yusuf, B.H., Nigeria's Wind Energy Potentials: the Path to a Diversified Electricity GenerationMix. International Journal of Modern Engineering Research (IJMER). Vol.2, Issue.4, July-Aug. 2012 pp-2434-2437

[13] Adekoya, L.O. and Adewale, A.A. (1992). Wind energy potential of Nigeria. Renewable Energy. 2: 35-39

[14] Ojosu, J.O. and Salawu, R.I. (1990). A survey of wind energy potential in Nigeria. Solar and Wind Technology, 7: 155-167

[15] Lehmeyer (International) Consultants (2005). Report on Nigeria wind power mapping projects Federal Ministry of Science and Technology, Abuja

[16] Fagbenle, R. L. and Karayiannis, T.G. (1994). “On the wind energy resource of Nigeria". International Journal of Energy Research. 18: 493-508

[17] Adaramola, M.S. and O. M. Oyewola (2011). Wind speed distribution and characteristics in Nigeria, ARPN Journal of Engineering and Applied Sciences, Vol. 6, No. 2

[18] Mahyoub, H. A. and Ahmed, A., "Monthly and Seasonal Investigation of Wind Characteristics and Assessment of Wind Energy Potential in Al-Mokha, Yemen," Energy and Power Engineering, 2012, 4, 125-131
[19] Algifri, A.H., "Wind Energy Potential in Aden-Yemen," Renewable Energy, Vol. 13, No. 2, 1998, pp. 255-260. Doi:10.1016/S09601481(97)00069-4

[20] World Wind Energy Report, "Report World Wind Energy Association (WWEA)," WWEA, Bonn, 2011

[21] The European Wind Energy Association, "Wind in Power 2010 European Statistics," EWEA, Brussels, 2011

[22] Ouammi, A., Sacile, R. and Mimet, A. (2010) Wind Energy Potential in Liguria Region. Renewable and Sustainable Energy Reviews, 14, 289300. http://dx.doi.org/10.1016/j.rser.2009.07.006

[23] Premono, B.S., Tjahjana, D.D.D.P. and Hadi, S. (2016). “Wind Energy Potential Assessment to Estimate Performance of Selected Wind Turbine in Northern Coastal Region of Semarang-Indonesia." International Conference on Engineering, Science and Nanotechnology (ICESNANO), AIP Conference Proc. 1788,030026-1030026-10; doi:10.1063/1.4968279

[24] Saedi, D. Mirhossenini, M., Sedaghat, A. and Mostafaeipour, A (2011). Renewable Sustainable Energy Rev. 15,3558-3569

[25] Omar, A. and Mohammad A. (2015). Assessment of Wind Energy Potential as a Power Generation Source in the Azraq South, Northeast Badia, Jordan. Modern Mechanical Engineering. Scientific Research Publishing. Available at http://www.scirp.org/journal/mme

[26] Gupta, R. \& Biswas, A. (2010). Wind Data Analysis of Silchar (Assam, India) by Rayleigh's and Weibull Methods. Journal of Mechanical Engineering Research, 2, 10-24

[27] Weisser, D. (2003). "A Wind Energy Analysis of Grenada: An Estimation Using The Weibull Density Function". Renewable Energy, 28, 1803-1812

[28] Lun, I. Y. F. \& Lam, J. C. (2000). "A Study of Weibull Parameters Using Long-term Wind Observations". Renewable Energy, 20, 145-153

[29] Seguro, J. V. \& Lambert, T. W. (2000). "Modern Estimation of the Parameters of Weibull Wind Speed Distribution for Wind Energy Analysis". Journal of Wind Engineering and Industrial Aerodynamics, $85,75-84$

[30] Ulgen, K. \& Hepbasli, A. (2002)." Determination of Weibull Parameters for Wind Energy Analysis of Izmir, Turkey". International Journal of Energy Research, 26, 495-506

[31] Celik, A. N. (2004). A statistical analysis of wind power density based on the Weibull and Rayleigh models at the southern region of Turkey. Renewable Energy, 29, 593-604

[32] Gupta, R. \& Biswas, A. (2010). Wind Data Analysis of Silchar (Assam, India) by Rayleigh's and Weibull Methods. Journal of Mechanical Engineering Research, 2, 10-24

[33] Zaharim, A., Razali, A. M., Abidin, R. Z. \& Sopian, K. (2009). Fitting of Statistical Distributions to Wind Speed Data in Malaysia. European Journal of Scientific Research, 26, 6-12.

[34] Nze-Esiaga, N. and Okogbue, E.C. (2014). "Assessment of Wind Energy Potential as a Power Generation Source in Five Locations of South Western Nigeria", Journal of Power and Energy Engineering, 2 , 1-13. Available at http://dx.doi.org/10.4236/jpee.2014.25001

[35] Fagbenle, R.O., Katende, J., Ajayi, O.O. and Okeniyi, J.O. (2011) "Assessment of Wind Energy Potential of Two Sites in North-East, Nigeria". Renewable Energy, 36, 1277-1283. Available at http://dx.doi.org/10.1016/j.renene.2010.10.003. 